\title{
Sanal Marka Topluluklarının Markalama Çerçevesinde Kullanımı: PlayStation Türkiye Forumu Örneği'
}

\author{
Kamile Elmasoğlu
}

Öz

Bu çalışmada, sanal marka topluluklarının markalama çerçevesinde kullanımına ilişkin bir değerlendirme sunmak hedeflenmiştir. Bu hedef dâhilinde, çalışmada önce sanal marka topluluklarına değinilmiştir. Ardından markalama ve sanal marka topluluklarının markalama üzerindeki rolü tartışılmıştır. Çalışmanın yöntem aşamasında, bir sanal marka topluluğu olan PlayStation Türkiye Forumu, kalitatif araştırma tekniği olan doküman tarama yöntemiyle, 2 Mart- 5 Nisan 2017 tarihleri arasında incelenmiştir. PlayStation Türkiye Forumusnun etkinlikleri, bir marka topluluğunun unsurlarını oluşturan «aidiyet bilinci», "ritüel ve gelenekler" ve "ahlaki kurallar" başlıkları altında, markalama çerçevesinde ele alınmıştır. Çalışmanın sonuçları, PlayStation Türkiye Forumu^nun, marka topluluğu unsurlarını; üyeler ile samimi ilişkiler geliştirmek, markanın tanınırlığını, üye sayısını ve değerini artıımak gibi amaçlar doğrultusunda kullandığını göstermektedir. Çalışmaların bulguları genel olarak değerlendirildiğinde, sanal marka topluluklarının markalama noktasında etkin bir rol üstlendiği söylenebilir.

Anahtar Kelimeler: Sanal Marka Topluluğu, Markalama, PlayStation Türkiye Forumu

\section{Use of Virtual Brand Communities as part of Branding Works: Example of PlayStation Turkey Forum}

\begin{abstract}
The study has the purpose to present an evaluation of the use of virtual brand communities as part of brandingprocess. Accordingly, the virtual brand communities were mentioned at the beginning of the study. Then, branding and the role of virtual brand communities in branding were discussed. In the methodology section of the study, PlayStation Turkey Forum, a virtual brand community, was examined for a period between 2 March and 5 April 2017 by using the document review method, which is a qualitative research technique. The activities of PlayStation Turkey Forum were evaluated under "the sense of belonging", "rituals and traditions" and "ethics" which are the features of a brand community as part of branding process. The results of the study reveal that PlayStation Turkey Forum used the features of brand communities to develop sincere relationships with the members, to increase the brand's recognition, as well as the number of members and brand value. All in all, it would not be wrong to say that virtual brand communities play an important role in terms of branding.
\end{abstract}

Keywords: Virtual Brand Communities, Branding, PlayStation Turkey Forum

\footnotetext{
1 Bu makale, 3-6 Şubat 2016 tarihlerinde, IASSR tarafından Fransa'da düzenlenen, 9. Avrupa Sosyal ve Davranış Bilimleri Konferansı'nda, "The Use of Virtual Brand Communities in Branding" başlığı altında sözlü olarak sunulan ve özeti yayımlanan bildirinin yeniden gözden geçirilerek düzenlenmiş halidir.

2 Arş. Gör., Gazi Üniversitesi, İletişim Fakültesi, Halkla İlişkiler ve Tanıtım Bölümü
} 


\section{Giriș}

S osyal medyanın gelişimi ile birlikte tüketici kararları ve davranışları sanal ortama taşınmıştır. Ayrıca, tüketici kararlarının bilişsel ve sosyal bağlamı da değişmeye başlamıştır. Bu ortamda, en etkili pazarlama iletişim biçimlerinden olan kişilerarası iletişim, geleneksel yapıdan sıyrılarak tüketicinin aktif 'üretici' olduğu, karşılıklı paylaşım ve etkileşim temeline dayanan sosyal medya mecraları ile birlikte yeni bir boyut kazanmıştır. Daha önceleri sosyal izolasyona neden olacağı düşünülen internet, tersine tüketicilere alternatif bir sosyal ortam açmış ve bireyleri fiziksel sınırlardan özgürleştirerek istediği kimlikleri ve deneyimleri herhangi bir yer ve zaman kısıtlaması olmaksızın tüketmelerine ve müzakere etmelerine olanak sağlamıştır (Dedeoğlu ve Üstündağlı, 2011: 24). Sosyal medya ortamları; katılım ve içerik yaratma özellikleriyle kullanıcılara ürünün bir parçası olmasını sağlamaktadır. Daha önce büyük organizasyonlar tarafından üretilen ürün, içerik ve bilgiler artık sosyal medya aracılığıyla tüketicilerin ve kullanıcıların katkısıyla oluşturulmaya başlamıştır. Tüketiciler bu ürün, içerik ve bilgilerin oluşması veya oluştuktan sonra geri bildirim alınması aşamasında hem büyük organizasyonlara yardımcı olmakta hem de büyük organizasyonlara gerek duymadan internette oluşturulan topluluklar sayesinde kendi içerik, bilgi ve ürünlerini oluşturabilmektedir (İşlek, 2012: 64). Özellikle internet teknolojisinin gelişmesi ve erişiminin tüm dünyada yaygınlaşması ile beraber, sosyal medya ortamları çeşitlilik kazanmış ve tüketicilerin rol ve işlevleri de artış göstermiştir. Tüketiciler geleneksel rolleri olan mevcut içeriği gözlemleyen, yorumlayan ve tüketen pasif taraf olmanın ötesine geçerek, içeriği oluşturan ve biçimlendiren aktif bir konuma yükselmiştir.

Web 2.0'ın işletmelere sağladığı en önemli özelliklerden biri, çevrimiçi ya da sanal paydaş topluluklarının oluşumunu kolaylaştırmasıdır. Bu gruplar hemen hemen aynı görüşleri paylaşan, belli bir marka, ürün veya hizmet üzerine odaklanan, birbirleriyle çevrimiçi etkileşime giren topluluklardır. Günümüzde kurum, marka, ürün veya hizmet üzerine odaklanan çevrimiçi topluluklara sıkça rastlanmaktadır (Alikılıç, 2011: 1516). İşletmeler, tüketiciler ile ilişkiler kurmak, marka sadakati oluşturmak ve uzun dönemli değişim ilişkileri yaratmak gibi çeşitli amaçlar doğrultusunda, sanal paydaş topluluklarından yararlanmaktadırlar (Erdoğan ve Torun, 2009: 46). Bu topluluklar, kablolu ve kablosuz internet imkânları sayesinde farklı coğrafi bölgelerde yer alan ve benzer ilgi alanlarına sahip olan katılımcıları bir araya toplamaktadır. Bu ilgi alanları çok çeşitli olabileceği gibi herhangi bir markaya duyulan özel ilgiyi de kapsamaktadır. Bu sanal ortamlarda, belirli bir markayı kullanan kişiler, marka ile ilgili bilgi ve deneyimlerini paylaşmaktadırlar. Bu sayede, markanın diğer kullanıcılarla olan ilişkileri gelişmekte ve bir topluluk bilincinin doğması kolaylaşmaktadır. Bu durum, markanın tanınırlığını ve kullanımını da arttırmaktadır.

Sanal marka toplulukları ile ilgili uluslararası literatür incelendiğinde; sanal marka topluluklarında müşteri katılımını (Wang vd., 2015), değer yaratımını (Healy ve McDonagh, 2013), topluluk tanıtımını ve marka sadakatini (Casalo vd., 2010), marka farkındalığını (Wang vd., 2016), marka güveni ve tüketici tutumunu (Jung vd., 2014), müşteri etkileşiminin fikir üretimine olan etkisini (Wu ve Fang, 2010) ve hayran katılımının nasıl artırılabilirliğini (Rosenthal ve Brito, 2017) araştırmak amacıyla yazılmış çalışmalara ulaşılmıştır. 
Türkiye'deki ilgili literatür incelendiğinde ise; sanal marka topluluklarında topluluk üyelerinin marka ile özdeşleşme düzeylerinin öncülleri ve sonuçlarını (Ventura, 2012), beklenen faydalar ve markaya adanmışlık ilişkisini (Aslan ve Öztürk, 2015), müşteri sosyalizasyonu bağlamında Harley Davidson örneğini (Demir, 2008), sanal toplulukların satın alma kararlarına olan etkisini (Bahar, 2015), yeni bir rekabet alanı olarak işletmeler için önemini (Uzkurt ve Özmen, 2006), bir ilişkisel pazarlama aracı olarak rolünü (Erdoğan ve Torun, 2009) ve sanal toplulukların bir türü olarak sosyal ağ sitelerinin pazarlama iletişim kanalı olarak işleyişini (Akar, 2010) araştırmak amacıyla yazılmış çalışmalara ulaşılmıştır. Çalışmaların birbirinin eksik yönlerini tamamlayıcı yönde olduğu, ancak yine de yeterli düzeyde olmadığı düşünülmektedir.

Bu çalışmanın temel hedefini ise, sanal marka topluluklarının markalama çerçevesinde kullanıma yönelik genel bir değerlendirme sunmak oluşturmaktadır. Bu hedef dâhilinde, çalışma kapsamında öncelikle sanal marka topluluklarına değinilmiştir. Ardından, markalama ve sanal marka topluluklarının markalama üzerindeki rolü tartışımıştır. Çalışmanın araştırma bölümünde ise, konuyla ilişkili olarak yargısal örneklem metodu ile seçilen PlayStation Türkiye Forumu'nda yer alan bilgi ve belgeler, doküman tarama yöntemi ile incelenmiştir. PlayStation Türkiye Forumu'nun etkinlikleri; Muniz ve O'Guinn'in belirttiği (2001), bir marka topluluğunun temel unsurlarını oluşturan "aidiyet bilinci", "ritüel ve gelenekler" ve "ahlaki kurallar" özelliklerini, markalama çerçevesinde ne şekilde kullandığı yönünde incelenmiştir.

\section{Sanal Marka Toplulukları}

Sanal topluluklar çoğunlukla çevrimiçi topluluklardır. Belirli ortak normlara ve uygulamalara sahip olan grup üyeleri, belirli ahlaki standartların oluşmasını ve sürmesini sağlarlar. Bu gruplarda bir değişim gerçekleşmektedir. Aynı zamanda, bağlıık duydukları ortak semboller ve ritüeller vardır. Bu özelliklerden dolayı, bu gruplar topluluk olarak nitelendirilebilir (Uzkurt ve Özmen, 2006: 26). Illk olarak Rheingold tarafından adlandırılan sanal topluluk kavramı, yeterli sayıda bireyin sanal alanda kişisel ilişki ağları geliştirmek amacıyla yeterince uzun süre boyunca ve yeterli duyguyla kamusal iletişim kurduğu sosyo-kültürel gruplaşmalar olarak tanımlanmaktadır. Bu gruplarda özellikle topluluk/cemaat niteliği ön plana çıkmaktadır (Dedeoğlu ve Üstündağlı, 2011: 24). Sanal topluluklar, genel olarak, sosyalleşme ve işbirliği amacıyla bir araya gelen işbirlikçi medya sistemi kullanıcılarını ifade etmektedir. Web tabanlı iletişimin ilk destekçileri, "sanal ilişkilerin" bağımsızlığına odaklanmıştır. Böylelikle, kullanıcı katılımı yoluyla "topluluk" duygusuna ulaşılmıştır (Akar, 2010: 109). İstedikleri zaman ve uzamda bir araya gelen bu topluluklar, ortak ilgi alanlarına yönelik paylaşımlarda bulunmaktadırlar. Bu paylaşımlar sayesinde grup üyeleri, zaman içinde birbirlerini tanıyarak ve birbirlerinin farklılıklarını benimseyerek mevcut ilişki durumunun güçlenmesini sağlamaktadırlar. Böylece bir topluluk bilincinin intiyacını oluşturan, sosyal etkileşim ve iletişimin zemini oluşmaktadır.

Sanal veya çevrimiçi topluluklar; teknik altyapı gerektiren platformlarda bir araya gelen insanların diğerleri ile etkileşim içinde bulunduğu, özel bir ilgi alanı ile ilişkili, sosyal ilişkilere imkân tanıyan ve insanların biz bilincine sahip olabileceği insan gruplarıdır (İşlek, 2012: 61). Sanal topluluklar, benzer ilgi alanlarına sahip insanların internet üzerinden birbirlerini bulabileceği ve sohbet edebileceği yerlerdir. Ticari işlem ve müzayede yapılan yerler olarak kurulan sanal topluluklar, ilk olarak ticari değil de kafe 
işlevi görmüştür (Gupta ve Kim, 2004: 2679). Ancak, sanal topluluklar zaman içinde kitlesel üretim ve piyasada artan rekabet sonucunda, işletmelerin mesajlarını iletmek üzere yararlandıkları ticari kanallardan biri haline gelmiştir. Böylece sanal topluluklar üyelerin karşılıklı iletişim kurabildikleri sosyal bir ortam olma özelliğine ek olarak, işletmelerin belirli menfaatler doğrultusunda tasarladıkları mesajlarını iletebildikleri ticari bir kanal olma özelliğini de kazanmıştır.

Sanal marka toplulukları ise, üyeleri arasında ilgi ve hayranlık duyulan belirli bir ürünün zaman ve mekân kısıtı olmaksızın kullanımına dayalı yapılandırılmıştır bir gruptur (Muniz ve O'Guinn, 2001: 414). Birbirlerine karşlıklı duygusal bağlılık hisseden ve gelişmiş bir sosyal kimliğe sahip olan topluluk üyeleri, belirli bir markaya yönelik ortak heyecanı ve coşkuyu paylaşmaktadırlar. Üyeler ayrıca ortak efsane, değer ve törenleri bünyesinde barındıran kendilerine özgü bir dil yapısına sahiptir (Bagozzi ve Dholakia, 2006: 45; Cova ve Pace, 2006: 1095'ten aktaran; Ventura, 2012: 198). Marka topluluğu, bir markanın hayranları arasındaki bir dizi yapılandırılmış sosyal ilişkilere dayalı, özelleştirilmiş ve coğrafik sınırları olmayan bir oluşumdur. Bu toplulukların merkezinde markalandırılmış ürün ya da hizmet söz konusudur (Muniz ve O'Guinn, 2001: 412). Bu nedenle, sanal marka topluluğu üyeleri, genellikle organizasyondan bağımsız olarak, genellikle ürünle ilgili kapsamlı bilgilere sahiptirler ve ürünle ilgili tartışmalara katılırlar. Ayrıca, üyeler, yeni ürünlere yönelik fikirler geliştirilirken ve problemler çözülürken birbirlerini desteklerler (Wu ve Fang, 2010: 570). Belirli bir marka kullanıcıları ve sempatizanlarının bir araya gelerek oluşturdukları bu sanal marka toplulukları, markaya yönelik her türlü bilginin paylaşıldığı ortak bir platformdur. Üyeler bu platformda, hem markaya ilişkin fikirlerini hem de üyeler tarafından belirlenen herhangi bir konu ile ilgili kanaatlerini paylaşmaktadırlar. Böylece, üyeler kullanıcısı oldukları markanın tanınırığını ve bilinirliğini arttırırken, istedikleri sosyal kimliklere bürünmekte ve sohbet edebilecekleri yeni arkadaşlar edinmektedirler.

Muniz ve O'Guinn'in belirttiği üzere; bir grubun topluluk olabilmesi için üç önemli özelliği bünyesinde barındırması gerekmektedir. Birinci özellik, üyelerin birbirlerine karşı hissettiği içsel bağlantı ve toplulukta olmayanlardan ayrılan bir kolektif his olan "aidiyet bilinci"dir. İkinci özellik, bir topluluğun paylaştığı "ortak ritüel ve geleneklerin varlığı”dır. Bir topluluğun ortak tarihi, kültür ve bilincini bunlar sürdürür. Üçüncü özellik ise, bir toplulukta bir bütün olarak topluluğa ve onun bireysel üyelerine karşı taşınan zorunlulukları ve görev hissini oluşturan "ahlaki sorumluk hissi”dir (Muniz ve O'Guinn, 2001: 413). Paylaşılan tutumlar ve görünen benzerliklerin yüksek oluşu aidiyet bilincinin belirleyici unsurlarıdır. Ortak ritüel ve geleneklerin varlığı, belirli davranışsal norm ve değerleri kutlamak ve öğretmek için tasarlanmıştır. Ahlaki sorumluluk anlayışı için ise, kolektif bir hareketten bahsetmek mümkündür (Tosun, 2010: 293). Bir grubun topluluk vasfına sahip olabilmesi için gerekli olan bu üç özellik aracılığıyla, üyeler arasında karşılıklı sadakate dayalı uzun süreli bir ilişki biçiminin gelişmesi söz konusu olabilir. Üyeleri bir araya getiren ve onlara bir yol haritası sunan bu özellikler, topluluğu ayakta tutan üç sacayağına benzetilebilir.

Marka topluluğu, bir pazarlama aracı olarak büyük bir potansiyele sahip bir olgudur. Bir markaya ortak bağlılık duyan tüketiciler artık birbirleriyle bilgisayar üzerinden bağlantı kurabilirler. Bu ağlar genellikle, markanın yaratıcılarından bağımsız olarak ortaya çıkar. Topluluk üyeleri, kurumlardan gelecek tepkilere karşı önlem almış olsalar da, bir kurumun ürünü üzerine yapılan doğal konuşmalar, güçlü bir geribildirim sağlar 
(Solomon, 2004: 176). Bu toplulukların bazıları, genişleyen bir sosyal iletişim ağı vasıtasıyla, dijital içeriğin ve etkileşimin yaygınlaşmasını desteklemektedir. Çünkü sanal topluluklar; müşteri ilişkileri yönetimi ve pazarlama aktiviteleri açısından, perakendeciler, müşteriler ve satıcılar arasındaki işbirliğinin potansiyelini arttırmaktadır. Sosyal ilişkilere imkan tanıyan internet teknolojisi aracılığıyla, işletmeler marka topluluklarındaki alıcı ve satıcı etkileşimi üzerinde durmaktadır (Wang vd., 2016: 57). $\mathrm{Bu}$ nedenle, bir marka topluluğu, şirketler için yalnızca üyelerin birbirleriyle kaynaşıp marka ile ilgili deneyimlerini paylaştığı sosyal bir ortam olma özelliğinden daha fazla anlam ifade etmektedir. Şirketler, marka toplulukları aracılığıyla markanın bilinirliğini ve tanınırlığını artıımanın yanı sıra; yeni ürünlerin tanıtımını yapmakta, yeni müşteriler kazanmakta, büyük gelirler elde etmekte ve kriz durumlarını bilginin hızlı dolaşımı sayesinde kolaylıkla atlatabilmektedirler.

\section{Markalama}

Markalama bir kuruma ait tüm ürünlerin marka denkliklerinin ve değerinin maksimize edilebilmesi için kullanılacak marka unsurlarının kategorize edilmesidir. Markalama aracılığıyla, yeni ve mevcut ürünlere uygulanacak olan yeni veya farklı marka unsurlarının niteliğine karar verildiği ifade edilebilir (Tosun, 2010: 169). Markalama sürecinde, müşterilerin markayla kurduğu her etkileşim düzeyinde ortaya çıkan deneyimin olumlu bir algı oluşturacak şekilde planlanması gerekmektedir. Burada ifade edilen deneyim, markanın satın alınması sırasında, sonrasında ve alınan ürünün kullanımı aşamasında elde edilen tatmin olabileceği gibi, markayı kullanmaktan dolayı sahip olunan duygusal faydanın yarattığı doyum olarak da düşünülebilir (Elden, 2009: 103). Dolayısı ile markalama süreci ile hem ürün hem de tüketici için uygulanacak olan stratejilere karar verilir. Ürüne yönelik uygulanacak stratejilerde ürünün değerinin arttırılmasına; tüketicilere yönelik uygulanacak stratejilerde ise, tüketici tatmin düzeyinin yüksek tutulmasına özen gösterilmelidir.

Markalama, ürünün satın alınma öncesi ve sonrası tüm aşamalarında planlanan etkinlikleri kapsayan uzun vadeli bir süreçtir. Markalamada temel amaç, ürünü farklılaştırmak ve ürüne değer katmaktır. Bir marka önemli bir değer kaynağı olduğu için, yatırım ve özel bir yönetim gerektirir. Bu doğrultuda, lider markalara sahip olan şirketlerin genellikle yaptıkları şeyler; markayı büyütmek, markanın değerini arttırmak ve performansını yükseltmektir (Brymer, 2003: 68). Ürünü gösteren bir işaret olarak değerlendirilen markalama çalışmaları ile işletme yöneticilerinin marka hakkında vermeleri gereken kararlar saptanmaktadır. Ürünün fiziksel şekli, performans özellikleri, kalitesi ve tasarımı gibi unsurlarına eklenecek yeni değerler aracılığıyla, markaların etkinliği arttırılmaktadır (Tek ve Özgül, 2010: 302). Çünkü markaya eklenecek olan her değer, marka tutumunu olumlu yönde besleyerek satın alma davranışını etkiler. Ayrıca, markanın rakipleri arasından kolayca ayırt edilmesini sağlar ve markanın tüketicilerin zihnindeki önemini artırarak marka sadakatinin oluşmasını kolaylaştırır.

Markalama; kamu, özel sektör ve sivil toplum örgütlerinde, 20. yüzyılın dörtte üçünü oluşturan bir süreçte, çoğunlukla tüketici mal ve hizmetlerini ön planda tutan bir konumdaydı (Blackett, 2003: 20). Ancak, günümüzde endüstriden üretime ve hizmet sektörüne değin çok geniş bir alanda büyük çapta bir değişim yaşanmıştır. Finansal ve boş zaman hizmetlerine olan talep artışı, insanların ürünlere daha seçici davranması ve ürünleri zor beğenmesi gibi nedenler, markalama çalışmalarına olan kavrayışın önemini 
arttırmıştır (Blackett, 2003: 21). Ayrıca, pazarlama anlayışında yaşanan gelişmeler ile birlikte; fiziksel mallar, hizmetler, internet aracılığıyla satılan ürünler, spor, sanat ve eğlence olayları, coğrafik yerler ve fikirler gibi tüm ürün kategorilerinin markalanması söz konusu edilmeye başlanmıştır (Ural, 2009: 6-12). Bu durum, markalama çalışmalarının önemini artırırken markalama yapılacak olan alanın da çeşitliliğini zenginleştirmektedir. Planlı amaçlar doğrultusunda gerçekleştirilen markalama çalışmaları, yalnızca yeme, içme ve giyinme gibi zorunlu ihtiyaçları karşılayan ürünler için değil; serbest zaman etkinliklerini ve çeşitli hizmet dallarını kapsayan alanlar için de uygulanması gereken faaliyetleri içermektedir.

Markalama çalışmaları gerçekleştirecek olan şirketlerin amaçlarının neler olabileceğine dair sistematik bir çalışma yapılmıştır. Çalışma kapsamında, 1976 yılından sonra üretilen binlerce ürünün yer aldığı bir listeden 276 farklı marka seçilmiştir. Çalışmada, nadiren satın alınan ürünler ve tekstil ürünleri dâhil, farklı kategorilerden 115 marka bulunmaktaydı. Bazı markaların bir amacı taşıdığı görülürken, çoğu markanın birden çok amacı taşımakta olduğu görülmüştür. Ancak çalışma genel olarak değerlendirildiğinde, markalama amaçlarının 7 farklı noktada toplandığı saptanmıştır (Tauber, 1988: 29). Bu amaçlar aşağıda kısaca belirtilmektedir (Tauber, 1988: 29; Tosun, 2010: 169). Amaçlar gözden geçirildiğinde; markalama faaliyetlerinin; genel olarak kurumun, markanın, ürünün geliştirilmesi ve tüketicilerin tatmin düzeyinin yüksek tutulması üzerine yoğunlaşmakta olduğu görülmektedir.

- Belirli bir ürünü farklı biçimlerde sunmak

- Belirli bir ürüne ayırt edici bir tat, içerik veya bileşen eklemek

- Belirli bir markayı, başka bir marka ile bileşik biçimde sunmak

- Ana markayı tüketicilere bazı avantajlar sağlayan başka yan ürünlerle birlikte sunmak

- Ürünü, kurumun algılanan uzmanlık alanı kapsamında sunmak

- Ürünü, markanın farklılaştırıcı yararlarına dayalı özellikleri kapsamında sunmak

- Ürünü, markanın farklılaştırıcı imaj ve saygınlığına dayalı sunmak

\section{Sanal Marka Topluluklarının Markalama Üzerindeki Rolü}

Günümüzde markalama ve halkla ilişkiler uzmanları, sosyal medyada çevrimiçi paydaşların önemini kavramaya başlamıştır. Çünkü sosyal medya ortamları; bloglar, çevrimiçi video ortamları, forumlar, sosyal ağlar, vb. neredeyse milyonlarca insanın bir tüketici olarak seslerini birbirine duyurması açısından çok önemli bir araç haline gelmiştir. Bu kişiler seslerini sadece milyonlara değil, bu yolla firmalara da duyurmaya başlamışlardır (Alikılıç, 2011: 14). Ancak internette yaklaşık 2 milyon insanın çevrimiçi toplulukta yer almasına rağmen, bunların içinde markalar ile özel bir ilişkiye sahip bulunanların oranı yüzde 0,1'e ulaşmaktadır. Belki de bu durum, neredeyse bütün markaların kullanıcıyı iletişimlerinin merkezine oturtmaktaki başarısızlıklarından kaynaklanmaktadır. Bu nedenle, markaya düşen rol, ortak bir zemin ve güçlü bir aidiyet duygusu yaratarak insanları birbirine bağlamaya çalışmaktır (Lindstrom, 2006: 194) Çünkü markaların insanlar arasında sevilebilmesi ve başarıya ulaşabilmesi için, geleneksel medyanın sunduğu kanalların yanı sıra, alternatif medya kanallarında da yer alması gerekir. Bu noktada, sosyal medya ortamları marjinal hedef kitleye ulaşması, 
zaman ve mekan avantajları sağlaması ve maliyetinin düşük olması gibi nedenlerden dolayı işletmelere geniş imkanlar sunmaktadır.

Özellikle sanal marka topluluklarının markalama süreci içindeki önemini bilmek marka yöneticileri için çok önemlidir. Çünkü sanal marka topluluklarında üyelerin birbirleriyle karşılıklı etkileşime geçmesi ve tecrübelerini paylaşması söz konusudur. Üyelerin çeşitli aktivitelere katılması sonucunda topluluk bilinci oluşmakta ve bir topluluğa ait olma duygusu gelişmektedir. Böylece, marka ve topluluk üyeleri arasında güven ve adanmışıık artmaktadır (Aslan ve Öztürk, 2015: 63). Bugün pek çok marka sempatizanı, sanal marka topluluklarına katılmaktadırlar. Çünkü hem markanın ürün ve hizmetleri ile ilgili deneyim edinmek hem de belirli bir ürün, şirket ya da kullanıcılar hakkında bilgi elde etmek istemektedirler. Tüketicilerin sanal marka toplulukları ile ilgili kurduğu bağ; paylaşım, öğrenme, geliştirme, destekleme ve sosyalleşme gibi ikincil işlemleri kapsayan bir sözleşme niteliğindedir. Bu durumun pozitif sonuçları; markaya güvenin, sadakatin, farkındalığın ve pozitif ağızdan ağza iletişimin gelişmesidir (Rosenthal ve Brito, 2017: 376). Böylece sanal marka toplulukları ile tüketiciler sosyalleşme imkânı elde ederlerken, markalar ise planladıkları amaçlara ulaşma fırsatı yakalamaktadırlar. Her iki kesim için de sayısız avantajlara sahip olan sanal marka toplulukları, uygulama sahası her geçen gün artan önemli bir sosyal medya platformudur.

Bir markanın hayranları arasındaki bir dizi yapılandırılmış sosyal ilişkiler üzerine dayandırılmışolan sanal markatoplulukları; ürün bilgisiyaymak, hizmet desteği yürütmek ve müşterileri eğitmek için pek çok işletmenin yararlandığı bir internet platformudur. Çoğu işletme, sanal marka topluluklarını pazarlama aktiviteleri içine dahil etmektedir (Wang vd., 2015: 577). Sanal topluluklar, aynı zamanda, işletmelerin markalarıyla ilgili geri bildirim elde etmelerini kolaylaştıracak önemli bir kaynaktır. Tartışma gruplarında yapılacak tartışmalar ya da fikir alışverişleri marka yöneticileri için oldukça değerli bilgilerdir. Bunun nedeni, tüketicilerin marka algılamalarını, çağrışımlarını ve sadakatlerini öğrenmenin, hem daha kolay hem de daha hızlı gerçekleşmesidir. Bu iletişimin sürekli olarak gerçekleşiyor oluşu da bilginin güncelliğini kaybetmeden sürekli olarak elde edilmesi anlamına gelmektedir (Tosun, 2014: 657). Sanal marka toplulukları aracılığıyla, işletmeler karşılıklı ve uzun süreli ilişkiler geliştirerek, mevcut tüketicilerini daha iyi tanıyabilirler ve onlardan daha hızlı geribildirim alabilirler. İşletmeler, ayrıca, sanal marka topluluklarının etkin bir şekilde kullanımı yoluyla, büyük bir rekabet avantajı sağlayabilirler ve yeni fikirler elde edebilirler (Bahar, 2015: 65). Bu nedenle, sanal marka toplulukları, işletmeler için, müşteriler hakkında gereksinim duydukları anda bilgi elde etmeleri ve günceli yakından takip ederek değişimlere kendilerini kolayca uyarlamaları açısından önemli ve alternatif bir sosyal medya ortamıdır.

Sanal marka topluluklarının artan popülaritesi; tüketiciler için, tercih ettikleri markalara ilişkin deneyim ve coşku elde edebilecekleri; markalar içinse tüketicilere istenen yer ve zamanda ulaşılabilecekleri sosyal bir platform sunmaktadır. İletişimsel ve etkileşimsel yetenekleri ile sanal marka toplulukları, markalarını geliştirmeleri için işletmelere markalama sırasında rekabet avantajı sağlamaktadır. Dünyanın en büyük markalarından birçoğu; tanınmak, müşterilerine mesajlar göndermek ve aynı zamanda uzun vadeli tüketici- marka ilişkileri kurmak için sosyal ağlarda yer almaya başlamıştır (Islam ve Rahman, 2017: 97). Ayrıca, sanal marka topluluklarının müşteri katılımını arttıran; markaya etkin bir şekilde bağlılık, olumlu ağızdan ağza iletişim, güçlü marka bağlantıları, güven, sadakat ve memnuniyet gibi pozitif sonuçları mevcuttur (Rosenthal 
ve Brito, 2017: 376). Sanal marka topluluklarının farklı marka amaçlarına (tüketici tatmini, marka sadakati, geribildirim ve ürün inovasyonu vb.) olan katkısı; spor, motorlu taşıtlar (Harley Davidson), araba klüpleri, tema parkları ve Nutella gibi erişilebilir ürünler gibi çeşitli bağlamlardaki markalar için kanıtlanmıştır (Popp ve Woratschek, 2016: 184). İşletmeler, rakip markalar arasından ayırt edilebilmek ve mevcut sorunları kolayca atlatabilmek için alternatif yollar denemelidirler. Bu noktada, sanal marka toplulukları, işletmeler için, alternatif bir yol sunmaktadır. İşletmelerin sanal marka topluluklarına gereken önemi vermelerinin ve bu konuda yeterli donanıma sahip olmalarının onları uzun vadede başarıya taşıyacak önemli bir adım olduğu düşünülmektedir.

\section{PlayStation Sanal Marka Topluluğu}

PlayStation, Sony Computer Entertainment tarafından geliştirilen bir video oyun konsolu serisi markasıdır. Marka ilk olarak 1994 yılında Japonya'da tanıtılmış ve piyasaya sürülmüştür. PlayStation 1, dünya çapında 100 milyonun üzerinde bir satış rakamına ulaşan ilk video oyun konsoludur. Ardından üretilen PlayStation 2, 150 milyonun üzerinde elde ettiği satış ile en çok satılan video oyun konsolu olmuştur. Serinin üçüncüsü olan PlayStation 3 ise, 50 milyonun üzerinde bir satış elde etmiştir. Bu oyun konsollarını, 2004 yılında ilk taşınabilir oyun serisi olan PlayStation Portable, ardılı olan PlayStation Vita ise 2012 yılında piyasaya sürülmüştür. Günümüzde, PlayStation markası altında, dört ev konsolu, iki taşınabilir konsol, bir medya merkezi, çevrimiçi servis, telefon ile birlikte çeşitli oyun kumandası ve dergiler yer almaktadır (Wikipedia, 2017). Bu noktada, PlayStation markasını, özellikle serbest zamanlarda tercih edilebilecek alternatif ve zengin eğlence araçlarına sahip olması nedeniyle, bir oyun endüstrisine benzetmek mümkün olabilir.

$J$

aponya kökenli bir marka olan Sony tarafından üretilen oyun serilerini oluşturan PlayStation, görüntünün aktarılabildiği bir televizyon ve PlayStation aksesuarlarıyla oynanabilmektedir. Bu aksesuarlar; görüntü kablosu, güç kablosu, kumanda kolu ve hafıza kartı olarak sıralanabilir. PlayStation oyunları; aksiyon, strateji, zekâ, macera ve yarış olmak üzere pek çok farklı türlerde üretilmektedir. Bu sayede, çok geniş bir hedef kitlesine seslenmektedir (Altıntaş, 2013). PlayStation markası, pratik ve çok yönlü oyun grafikleri açısından çeşitli alternatifler sunmaktadır. Ayrıca, PlayStation oyun konsollarının gerçeğe yakın bir biçimde tasarlanmış olması oyunların ilgiyi toplamasında etkin olmuştur. Özellikle üretilen son oyunların içerdiği gelişmiş teknolojiler sayesinde, videolar yüksek çözünürlükte izlenebilmektedir (BilgiBaba, 2016). Ülkemizde de PlayStation oyunlarının oynanabildiği pek çok kafeler bulunmaktadır. Oyun ister satın alınarak, ister PC ve tablet üzerinden, isterse PlayStation kafelerinde oynanabilmektedir. Bu durum, oyunun çok geniş bir hedef kitleye ulaşmasında etkili olmaktadır.

PlayStation sanal marka topluluğu ise, Sony Interactive Entertainment Europe Limited tarafından, 1995 'ten bu yana oyuncular için açılmış olan bir topluluktur. Bu platformda, oyuncuların farklı deneyimlerle, maceralarla ve binlerce karakterlerle buluşmaları sağlanmaktadır. Özellikle PlayStation 4, PlayStation 3 ve PlayStation Vita gibi hizmetlerle oyuncuların iletişim kurmaları kolaylaştırılmaktadır (Playstation. com, 2017). PlayStation sanal marka topluluğu içinde, bir kullanıcı kendi sosyal medya hesabı ile diğer bireysel kullanıcılara ulaşabilir ve çevrimiçi oyun yükleyebilir. Her geçen gün daha da artan sosyal medya kullanımı ile, PlayStation marka topluluğu da 
global ölçekte büyümektedir. "Call of Duty" ve "Grand Theft Auto (GTA)" gibi bireysel oyunların bile kendilerine bağıı büyük toplulukları vardır. Örneğin GTA oyunu, çevredeki toplulukları oyuna bağlamak için gerçek hayattaki yerleri kullanır ve bireyler gibi bu topluluk da gerçekçidir (Hazeldine, 2015).

PlayStation sanal marka topluluğu, oyuncuların bağlanacağı bir çevrimiçi alan sağlama konusunda önemli bir rol üstlenmiştir. Kullanıcılar; farklı oyunlara, ilgi alanlarına veya intiyaç duydukları destek türüne göre, çıkarlarını gözetebilirler. Ayrıca topluluğun geri bildirim, savunma ve destek sütunları gibi hizmetlerinden yararlanabilirler. Topluluk, Playstation'ın bağı YouTube ve Twitter'daki sosyal medya kanallarıyla yakından bağlantılıdır. Böylece kullanıcılar hem PlayStation markası hem de kullanıcıların kendileri tarafından üretilen içeriği deneyimleyebilirler. Topluluğun en güçlü yönlerinden biri, kullanıcıların içerik oluşturabilmesidir. PlayStation, çevrimiçi oyun kliplerini doğrudan çevrimiçi yüklemesine olanak tanıyan yeni özellikleri ile birlikte, topluluğun gücünü arttırmaya devam edecektir. Markanın anahtar gücünü; kullanıcılar tarafından oluşturulan içeriğin neredeyse sınırsız kapasite ve ölçekte olması, farkındalık yaratması ve tüketici dokunmatik alanlarına değer katması gibi unsurlar oluşturmaktadır (Hong, 2015). Böylece marka; hem işletmenin çabası hem de topluluğun desteği ile kendini yenilemekte, büyümekte ve gelişmektedir. Üyelerin -kendi iletileriyle dünyalarını biçimlendirmeleri gibi- toplulukta aktif birer konum üstlenmeleri, markalar için ufuk açıcı fikirler vermektedir.

\section{Çalıșmanın Yöntemi}

Sanal marka topluluğunun markalama alanında kullanımına dair bir değerlendirme sunmak bu çalışmanın temel amacını oluşturmaktadır. Bu amaç dâhilinde, 'yargısal/ amaçlı örneklem' metoduyla seçilen, bir sanal marka topluluğu olan PlayStation Türkiye Forumu örneğinden yola çıkılmıştır. PlayStation Türkiye Forumu, en aktif sanal marka topluluklarından biridir. Bu forum aracılığıyla, PlayStation kullanıcıları ilgi alanlarına yönelik oyunları bulabiliyor ve açtıkları 'SEN' hesabı ile topluluk üyeleriyle tanışıp kaynaşabiliyorlar. Ayrıca kullanıcılar, PlayStation Türkiye Forumu>nda, yeni arkadaşlıklar edinmek istedikleri, oyunla ilgili destek veya tavsiyeye intiyaç duydukları, etkinlik ve yarışmalara katılmak istedikleri ve ilgilendikleri oyunları temel alan bir dizi bloga veya 'oyuna' katılmak istedikleri takdirde topluluğun imkânlarından kolaylıkla yararlanabilmektedirler.

Çalışma kapsamında, PlayStation Türkiye Forumunun, Muniz ve O'Guinn'in ifade ettiği (2001), bir marka topluluğunun temel unsurlarını oluşturan "ortak bilinç", "ritüel ve gelenekler" ve "ahlaki kurallar" özelliklerini markalama çerçevesinde nasıl kullandığı ortaya çıkartılmaya çalışılmıştır. Bu amaç doğrultusunda, Demir'in çalışmasında kullandığı yönteme benzer bir şekilde (2008: 120), çalışmada kalitatif araştırma yöntemlerinden biri olan doküman taraması yöntemi kullanılmıştır. Gurbetoğlu, doküman tarama yöntemini, algıların ve olayların doğal ortamda gerçekçi ve bütüncül bir açıdan ortaya konmasına ilişkin bir sürecin izlendiği bir araştırma yöntemi olarak tanımlar (2015: 13). Kümbetoğlu ise, doküman tarama yöntemini; niteliksel araştırmaların ön aşamasında ve diğer aşamalarında kullanılan ikincil veri kaynakları olarak tanımlar. Dokümanlar metin biçiminde olabileceği gibi görsel ve işitsel olarak da düzenlenmiş olabilir (2015: 145). Bu doğrultuda, doküman taraması kapsamında PlayStation Türkçe Forumu olarak tanımlanan gruba ait, «http://community.eu.playstation.com/ 
t5/T\%C3\%BCrk\%C3\%A7e-Forum/ct-p/cTR”3 isimli web sitesinde yer alan bilgi ve belgeler incelenmiştir. Forum ile ilgili bilgi ve belgelere; 2 Mart 2017- 5 Nisan 2017 tarihleri arasında ulaşılmıştır.

\section{Üyeler Arasındaki Aidiyet Bilinci}

PlayStation Türkiye Forumu tutkunları, marka ile kurdukları ortak biz bilincini pek çok şekilde göstermektedirler. PlayStation markası, dünyanın birçok ülkesinde, büyük bir çevrimiçi oyuncu topluluğuna sahip olmasına olanak tanıyan ve birbiriyle etkileşim halinde bulunan forumlara sahiptir. Topluluk üyeleri, bu forumlarda, oyun oynamanın dışında, diğer üyeler ile kaynaşarak ortak bir aidiyet bilincini farklı biçimlerde yansıtabilme imkânı elde etmektedirler. Örneğin, topluluğun sunduğu pek çok avantaj, fırsat, etkinlik ve organizasyonlardan yalnızca topluluk üyeleri yararlanabilmektedir. Topluluk üyeleri, intiyaç duydukları herhangi bir konu ile ilgili olarak istedikleri zaman birbirleri ile sohbet edip, birbirlerine danışabilmektedirler. Örneğin, bazı konular hakkında üyelerin paylaştıkları mesajlarda, topluluğun bir aidiyet bilincine sahip olma gayreti içinde olduğu görülmektedir. "Selam PlayStation Türkiye ailesi, daha fazla Türkçe fragman yükleyebilir misiniz? Başarılarınızın devamını diliyorum.» «Kardeşlerim bu oyunu aldım ama tam oynayamıyorum sizce bu neden kaynaklanmaktadır?» «Begüm, Ceyhun`a yeni bir PS4 alıyor ve Ceyhun mutluluktan havalara uçuyor! Ceyhun, Begüm`e PS4>ü sevdirme planında adım adım ilerliyor.» «PlayStation tutkunları için ideal haftasonu "Ye, uyu, oyna, tekrarla :)"

PlayStation topluluk üyeleri arasındaki aidiyet duygusunu pekiştiren en önemli unsurlardan biri de, PlayStation oyun konsolunun tüm tutkunlar için ortak oluşudur. PlayStation, televizyon veya diğer görüntülü ünitelere bağlanılarak kullanılabilen bir oyun konsolu ve konsol için üretilmiş olan dualshock isimli bir yön kontrol sisteminden oluşmaktadır. Dikdörtgen bir tasarıma sahip olan oyun konsolu, büyük bir depolama alanına ve DVD oynatıcısına; titreşim özelliği sayesinde sanal hislerin algılanmasına olanak sağlayan dualshock kontrol sistemi ise, çeşitli fonksiyonlar üstlenen düğmelere sahiptir. Modellerinde, renklerinde ve tasarımlarında farklılıklar olsa da, PlayStation oyun konsolunun ortak oluşu; biz bilincinin gelişmesine katkıda bulunmaktadır. Çünkü topluluk üyeleri, bu özellikler sayesinde, oyun DVD’lerini kolayca değiş tokuş edebilmekte, kırılan ve bozulan parçalarını değiştirip tamir ettirebilmekte ve her konuda birbirlerinden yardım alabilmektedirler. Topluluk üyeleri, ülkenin herhangi bir yerinde yer alan ve daha çok PlayStation oyun konsolu satın almak isteyip de alamayan oyun severlerin tercih ettikleri salonlara gittiklerinde, oradaki PlayStation tutkunları ile kaynaşarak tanışık oldukları konsollardan istedikleri oyunları karşılıklı oynayabilmektedirler. Böylece, birbirlerini hiç tanımayan bireyler, benzer bir ilgi alanı etrafında bir araya gelerek sosyalleşmekte ve biz bilinci edinmektedirler.

PlayStation topluluğu, PS Store menüsü altında, hem oyun severlerin topluluğa üye olmalarını teşvik etmek, hem de topluluk üyeleri arasındaki aidiyet bağlarını güçlendirebilmek amacıyla yalnızca topluluk üyelerinin yararlanabildiği indirimleri gerçekleştirmektedir. Üyeler, ortak bir ilgi alanına sahip olan bireylerin yer aldığı bir topluluğa üye olduklarında, hem topluluğun sunduğu imkânlardan yararlanabilmekte hem de her türlü gelişmelerden kolayca haberdar olabilmektedirler. Nitekim, üyeler

3 Detaylı bilgi için, URL: http://community.eu.playstation.com/t5/T\%C3\%BCrk\%C3\%A7e-Forum/ct-p/cTR 
için en önemli avantajlardan olan; "Kara Cuma" indirimleri, yaz indirimleri, yeni geliştirilen oyunlar için yapılan Vita indirimleri, çeşitli oyunlar için yapılan \% 60'a varan indirimler, belirli bir süre devam eden Big in Japan indirimleri ve dijital olarak satılan oyunlar için yapılan Dijital İndirimler gibi özel indirimlerden yalnızca topluluk üyeleri yararlanabilmektedir. Bu durum, markalama çerçevesinde satış, tanıtım ve marka sadakatinin gelişmesine katkıda bulunurken; üyeler arasında artan bilgi paylaşımı ve samimiyet neticesinde aidiyet bilincinin yerleşmesine yardımcı olmaktadır.

PlayStation topluluğunun, aidiyet bilinci içinde değerlendirilebilecek olan önemli uygulamalarından bir diğeri de, "PSN Kardeşliğidir." PSN Kardeşliği, iki kişinin birlikte, ücretini yarı yarıya ödeyecek biçimde, dijital oyun satın almasını sağlayan bir yöntemdir. Özellikle fahiş fiyatlı oyunların satın alımında, üyelerin daha az ücret ödemesine olanak tanıyan bu uygulama; oyun severlerin PS Store menüsünden aksiyon, macera, strateji ve savaş gibi farklı türlerdeki oyunları daha indirimli bir şekilde satın almasını sağlamaktadır. Kardeşlik yöntemi ile üyeler, bazı dijital oyunları yarı fiyatından bile daha düşük bir fiyatla satın alırken, bir aidiyet bilinci doğrultusunda hareket etmektedirler. Çünkü yaygın bir uygulama olan kardeşlik yöntemi ile üyelere, çeşitli oyunları tecrübe etme fırsatı sunulurken, aidiyet bilincinin gelişmesine katkıda bulunacak kardeşlik vurgusunun altı çizilmektedir. Böylece, ortak bir beğeni doğrultusunda satın alınan dijital oyunlar aracılığıyla; üyeler arasındaki ilişkilerin sürekliliği sağlanmaktadır.

\section{Üyeler Arasındaki Ritïel ve Gelenekler}

PlayStation Türkiye Forumu, Sony Intertactive Entertainment Europe Limited şirketi bünyesine dâhildir. Forumun temel amacı, 'hakkımızda' menüsünün altında yer alan bilgilerden çıkartıldığı üzere; video-oyunculuk alanında güvenli ve nitelikli oyun üretimini sürdürerek maksimum düzeyde başarı sağlamak ve nitelikli video oyun kullanım bilincini genç kitleler arasında yaygınlaştırmaktır. Böylece, video- oyunculuk alanının gelişmesine doğrudan katkıda bulunmaktır. Bu temel amaç doğrultusunda yola çıkan PlayStation Türkçe Forumu'nun sürdürdüğü temel çalışma konularının bir kısmı; herhangi bir PS one, PlayStation $\AA 2$, PlayStation $₫$ Portable, PlayStation $\AA 3$, PlayStation $®$ Vita, PlayStation ${ }^{\circledR} T V$ veya PlayStation ${ }^{\circledR} 4$ gibi oyun ve eğlence sistemlerini geliştirmek üzerine kuruludur.

Topluluk üyeleri, kendi aralarındaki iletişimi sürdürmek ve marka sadakati oluşturmak amacıyla, ulusal ya da tercihe bağlı olarak uluslar arası düzeyde çeşitli etkinlikler düzenlemektedirler. Düzenlenen bu etkinliklerin bir kısmı; Sahaların Kralı, Evolve, Little Big Planet, Shiftlings Eğlence ve The Order: 1886 gibi çeşitli yarışmalardan oluşmaktadır. Marka, bu yarışmalar ile rekabetin niteliğini arttırmaktadır. Oyuncular yepyeni oyuncularla tanışma ve cazip ödüllere sahip olma fırsatı yakalamaktadırlar. Yine sitenin 'Kapalı Yarışmalar' başlığı altında, özel kurallar ve şartlar sağlanarak başvuru yapılabilecek farklı yarışmalardan söz edilmektedir. Örneğin; "Nier: AutomataPod Tasarla", "Horizon Zero Dawn- Kendi makinenizi tasarlayın", "Bound Fotoğraf Modu" ve "Cadılar Bayramı Kapakları" yarışmalarına katılmak için belirli şartları taşımak gerekmektedir. Marka, bütün bu etkinlikleri daha çok sosyal ağ üzerinden duyurmakta ve düzenlemektedir.

Topluluğun düzenli olarak gerçekleştirdiği -ritüelleşmiş- temel etkinliklerinden biri de, PlayStation markasıyla özdeşleşen ESL oyun turnuvalarıdır. Lindstrom'a göre (2006: 
72); markalar, ritüellerin nasıl bir bağlamda ortaya çıktığını ve markalamaya açık bir ritüel potansiyelinin nerede bulabileceğini bilmek zorundadır. Dolayısıyla ürünün teknik özelliği ve potansiyeli neyse markanın buna uygun etkinliklerle adını duyurması doğru bir yaklaşım olur. Bu kapsamda, markalama çerçevesinde PlayStation markası için önemli olduğu düşünülen etkinliklerden biri, oyun turnuvalarıdır. ESL Turnuvaları olarak bilinen PlayStation'ın en popüler oyun turnuvaları; her şeyden önce oyuncuların kendilerini geliştirebileceği ve iddialı oyuncularla rekabeti yüksek maçlar yapabileceği bir arenadır. Bu turnuvalarda, PlayStation'ın başarı ortalaması yüksek oyuncularıyla mücadele etme fırsatı yakalanmakta, yarışılmakta ve eğlenilmektedir. Farklı bölgelerden birçok PlayStation tutkunu; oyunlar, turnuvalar ve maçlar hakkında konuşabilir, kendilerine yeni partnerler bulabilirler. Üstelik 50 avro gibi PSN Store kredisi kazanabilirler.

Etkinlerin yanı sıra, SEN (PSN) hesabına sahip olan topluluk üyelerinin geleneksel olarak yararlandığı avantajlı bir hizmet vardır. Bu hizmet, PlayStation Store menüsü ile bağlantılı olarak, üyelerin aynı zamanda bir de PSN cüzdanına da sahip olmalarıdır. PlayStation hizmet şartlarında belirtildiği gibi, bu cüzdana para yatırmak suretiyle, üyeler kendilerine sunulan hizmetten anında yararlanma imkânına kavuşmaktadır. Ancak PSN cüzdanına yatırılan paranın 24 ay içinde kullanılması gerekmektedir. Çünkü bu cüzdan, bir banka hesabı değildir. Bu cüzdanda yer alan paralar yalnızca, Forum'da yer alan ürünlerin satın alımında kullanılabilir. Bu cüzdanda yer alan paralar ile, oyunlar gibi dijital bir içerik, bir PlayStation Plus aboneliği gibi dijital bir hizmet, oyun eklentileri, mevsimlik pasolar, oyun içi ekipman, ön sipariş ve promosyon paketi gibi çeşitli ürünler satın alınabilmektedir.

SEN hesabına sahip olan topluluk üyelerinin geleneksel olarak yararlandığı avantajlı hizmetlerden biri de, yetkili oyun sistemlerinden en verimli şekilde yararlanılmasını sağlayan "PlayStation Plus" abonelik hizmetidir. Sitede yer alan PlayStation Plus Nedir? başlığı incelendiğinde, bu hizmetin PS4 ${ }^{\mathrm{TM}}$, PS3 ${ }^{\mathrm{TM}}$ ve PlayStation ${ }^{\circledR}$ Vita sistemleri için birinci sınıf oyun özelliklerine ve özel içerik tekliflerine erişilebileceği avantajı bir hizmet olduğu görülmektedir. Bu hizmetten PlayStation Store'dan aylık biçimde abonelik alınmak suretiyle yararlanılması tavsiye edilmektedir. Böylelikle, PlayStation Plus aboneliği süresince, ek bir ücret ödemeden, ileri sürüm oyun konsolları içinde belirli oyunlar indirilip oynanabilmektedir. Her ay bu seçeneklere yenileri eklenir ve oyun kütüphanesinin zenginleşmesi sağlanmış olur. Böylelikle, oyun çeşitliliği arttıkça, markanın üye sayısı ve hâsılatı da artmış olacaktır.

Tüm bunlar, markalama çerçevesinde, PlayStation topluluğunun, topluluk üyeleri arasında rekabete ve etkileşime dayalı bir iletişim biçimi oluşturmaya çalıştığı yönünde açıklanabilir. PlayStation markası, iletişim teknolojilerinin gücünden yararlanarak güçlenmekte olduğunun altını çizerek gelişime açık bir marka olduğunun izlenimini uyandırmaktadır. Bu durum, ayrıca, markanın yeniliklere ve farklılıklara açık bir marka olduğunu akla getirmektedir.

\section{Üyeler Arasındaki Ahlaki Kurallar}

PlayStation Türkiye Forumu'ndan yararlanmak için öncelikle, kullanım koşullarında belirtildiği gibi; Foruma üye olup kullanıcı adı ve şifre ile giriş yapmak gerekmektedir. Bir hesap oluşturmak için en az 18 yaşında olmak gerekmektedir. Oyunlar yaş 
derecelendirilmeleri ile kategorize edildiği için, kullanıcılar en az 7 yaşında olmalıdır. 18 yaşından küçük kullanıcılar ailelerinden izin almalıdır. Ardından, 'SEN' (Sony Entertainment Network) (eskiden PSN hesabı olarak kullanılırdı) olarak adlandırılan topluluk hesabı açılmalıdır. Bu hesap, giriş ID, soyadı, kimlik, adres detayları ve telefon numaraları gibi kişisel bilgiler içermektedir. Bu hesap "PSN Hizmet Şartları»nda belirtildiği gibi, kullanıcılara ücretli ve ücretsiz çok çeşitli çevrimiçi hizmetlere ve dijital içeriğe erişim hakkı vermektedir.

Ancak hesap açılırken kullanılan bilgilerin çevrimiçi güvenliği sağlamak amacıyla oyun sırasında paylaşılmaması tavsiye edilmektedir. Forum'da belirtildiği üzere; ilan panoları, sohbet odaları ve sitedeki diğer topluluk alanları halka açıktır. Bu nedenle, kimliği açığa çıkaracak bilgilerin bu alanlarda açıklanması uygun görülmemektedir. Forum'un elde ettiği bu bilgiler, sitenin 'yasal' menüsü altında belirtildiği üzere; PlayStation ürün, hizmet ve promosyonların kullanıcılara tanıtılması amacıyla kullanılabilmektedir. Çünkü var olan bu bilgiler kullanıcı profilinin çıkarılması ve hangi ürünün hangi kullanıcıya seslendiğinin tespit edilebilmesi açısından büyük önem taşımaktadır. PlayStation topluluğu; ürün, hizmet ve kampanyaları; kullanıcıların e-postalarına, yasanın izin verdiği ve bireylerden talep edildiği şekilde, pazarlama bilgileri içeren e-bülten yoluyla göndermektedir. Böylece marka, üyelerini en son ürünlerden, oyunlardan ve etkinliklerden haberdar etmektedir.

Ayrıca; PSN hizmet şartlarında belirtildiği gibi, SEN hesabına sahip olan üyeler, bazı ürünlerin nasıl kullanılacaklarına dair özel kurallara tabidir. Örneğin, bazı ürünler; ikamet edilen belirli bir ülkede, satın alma işleminin yapıldığı belirli bir hesap ile belirli bir dönem ya da dönemler boyunca, yalnızca uyumlu olan bir Sony sistemiyle ve işlemin yapıldığı hesap ile ilişkilendirilmiş belirli sayıda uyumlu aygıtla kullanılabilir. Dolayısıyla, topluluk üyelerinin ürünleri satın alırken ve kullanırken, uymak durumunda kaldıkları belirli kısıtlamalar söz konusudur. Bu durum markalama çerçevesinde değerlendirildiğinde; topluluğun, Sony markası şemsiyesi altında olduğunu göstermektedir. Sony markasının oluşturduğu kalite ve dayanıklılık izlenimi, 'hale' etkisi ile tüm topluluğa atfedilmeye çalışılmaktadır.

PlayStation Türkçe Forumu'nun eğlence ve bilgi paylaşım amaçlı kullanılmasını sürdürmek amacıyla, PlayStation topluluk yönetim ekibinin belirlediği "topluluk kuralları" bulunmaktadır. Bu topluluk kuralları, genellikle topluluk üyeleri arasındaki paylaşımların ve davranışların etik sınırlarını belirlemektedir. Örneğin; hesaplara ve kişilere kasten ve maksatlı saldırıları tanımlayan "trolleme"ler önlenmeye çalışılmaktadır. Topluluk kurallarında belirtildiği üzere; forumda arkadaşça iletişim kurulabilmesi için küfür, hakaret ve saldırı içeren mesajlar ile dil, din, ırk, cinsiyet, politik görüş ve kişisel özelliklere ilişkin ayrımcılık içeren mesajlar yasaklanmıştır. Tüm bu kurallar, çevrimiçi güvenliği sağlarken, üyeler arasındaki dayanışmayı arttırmakta ve markaya yönelik olumlu duyguları pekiştirip güçlendirmektedir. Böylece, marka, üyelerine ve topluma karşı sorumlu bir yaklaşıma sahip olduğu izlenimini uyandırmaktadır.

Ayrıca PlayStation Türkçe Forumıunda yer alan ‘kullanım koşulları'nda belirtildiği üzere; özellikle mesaj, yorum, resim, fotoğraf, video, oyun öğeleri ve oyun videoları gibi araçlar vasıtasıyla diğer kullanıcılarla kurulacak iletişimde, kanunlara uygun, terbiyeli ve saygılı bir biçimde hareket edilmesi gerekmektedir. Kısacası, topluluğun iletişim özelliklerinden yararlanırken, üye ve müşteri hizmetleri dâhil olmak üzere tüm 
tarafların menfaatleri göz önünde bulundurulmalıdır. PlayStation topluluk üyeleri bu özellikler sayesinde, internet üzerinden birbirleriyle emniyetli ve istikrarlı bir biçimde bilgi alışverişinde bulunmakta ve markanın tanınırlığını sürekli hale getirmektedirler.

Tüm bunlar, markalama çerçevesinde düşünüldüğünde, markanın hayran kitlesi arasında bilinçli ve sorumlu bir topluluk bilincinin oluşmasını sağlayan uygulamalardır. Topluluğa üye olduktan sonra, bu üyeliğin uzun süreli olacak şekilde devamını sağlayabilmek için güven ve istikrar gereklidir. Topluluk kuralları aracılığıyla, üyelerin güvenli bir oyun sürdürmesi ve üyeler arasında olumsuz sonuçlara yol açabilecek davranışların önceden engellenmesi sağlanmaktadır. Ayrıca, PlayStation topluluk üyeleri arasında; saygıya, güvene ve istikrara dayalı çift-yönlü bir iletişim biçimi gelişmektedir. Böylelikle, marka planlanan işletme amaçlarına ulaşmada aşama kaydetmiş olmaktadır.

\section{Sonuc}

Bu çalışmada günümüzde önemli bir yeri olan sanal marka topluluklarının markalama çerçevesinde nasıl kullanıldığı ele alınmıştır. Bu doğrultuda konuyla ilişkili olarak yargısal örneklem metoduyla, incelenmek üzere PlayStation sanal marka topluluğu seçilmiştir. PlayStation sanal marka topluluğu Sony Interactive Entertainment Europe Limited şirketi tarafından; kullanıcılar için farklı deneyim, macera ve binlerce oyun karakterinin ulaşılabilirliğini erişilebilir kılmak maksadıyla 1995 yılında kurulmuştur. $\mathrm{Bu}$ topluluk, PlayStation kullanıcılarını bir araya toplayarak bilgi paylaşımını mümkün kılmıştır. PlayStation sanal marka topluluğu dünyada birçok ülkede kullanıcılarına seslenmektedir. Bu kapsamda, çalışmayı sınırlandırmak ve incelemek üzere, PlayStation Türkiye Forumu'nun etkinlikleri ele alınmıştır.

PlayStation Türkiye Forumu`nun, Muniz ve O'Guinn'in bahsettiği, bir marka topluluğunun unsurlarını oluşturan aidiyet bilinci, ritüel/gelenekler ve ahlaki sorumluluklar doğrultusunda yer alan etkinlikleri, markalama çerçevesinde incelenmiştir. Buna göre, birinci özellik olan "aidiyet bilinci" kapsamında, büyük bir çevrimiçi oyuncu topluluğu olan PlayStation sanal marka topluluğunun birbiriyle etkileşim halinde bulunan pek çok forumlara sahip olduğu görülmektedir. Üyelerin, bu forumlarda yer alan birbirinden farklı konular hakkında paylaştıkları bazı mesajlarda topluluğun bir aidiyet bilincine sahip olabilme gayreti içinde olduğu görülmektedir. PlayStation oyun konsolunun tüm oyun severler için ortak oluşu da, aidiyet duygusunu pekiştiren unsurlardan biridir. Çünkü tasarımları ve modelleri farklı olsa da oyun konsolu ve dualshock isimli yön kontrol sisteminin aynı oluşu bireylerin bilgi paylaşımını ve samimiyetini artırmaktadır. Ayrıca, PlayStation topluluğunun gerçekleştirdiği 'PSN Kardeşliği' yönteminde de, üyeler dijital oyunları yarı fiyatına ortaklaşa satın alabildikleri için 'kardeşlik' vurgusunun altı çizilmektedir.

İkinci özellik olan «ritüel ve gelenekler" kapsamında, öncelikle PlayStation Türkiye Forumu'nun amaç ve çalışma biçimlerine değinilmiştir. Markanın temel amacı, video-oyunculuk alanının gelişmesine katkıda bulunmaktır. Marka, oyun ve eğlence sistemleri geliştirmek üzerine kurulu bir disipline sahiptir. Marka, rekabetin niteliğini arttırmak amacıyla, yeni oyuncularla tanışılıp cazip ödüllere sahip olunacak çeşitli etkinlikler düzenlemektedir. En bilinen örneklerden bir tanesi, markanın özellikle video oyun severlerin bir araya gelmesini sağlayan ritüelleşmiş ESL oyun turnuvalarıdır. 
Tüm bunlar, aynı zamanda, topluluğun üyeler için çeşitli avantajlar içeren paketler hazırladığını göstermektedir. Bu avantaj, fırsat, gelenek ve ritüeller; PlayStation sanal marka topluluğunun üyeleri ile arasını her daim temas halinde tutmasında ve samimi ilişkiler geliştirmesinde işe yaramaktadır.

Üçüncü özellik olan «ahlaki kurallar» kapsamında ise, PlayStation Türkiye Forumu'nun bir parçası olabilmek için gereken şartlardan söz edilmiştir. Üye olmak ve üye olarak kalmak için, PlayStation Türkiye Forumu'nda yer alan kullanım şartları, topluluk kuralları ve hizmet şartlarında belirtilen yükümlülükleri taşımak gerekmektedir. Tüm işlemlerden önce üye olmak gerekmektedir. Üyeler arasındaki iletişim biçimini belirleyen davranış kurallarına; güvenli ve istikrarı bir oyun seyri için ise topluluk kurallarına dikkat etmek gerekir. Özetle, PlayStation markası, tüm bu etkinlik, faaliyet ve hizmetleri sosyal ağların gücünden yararlanarak duyurarak, basit bir ürün olmanın ötesine geçmeye çalışmaktadır. Tanınan ve sevilen bir marka olan PlayStation markası gücünü, aynı zamanda topluluğun gücünden almaktadır.

\section{Kaynakça}

Alikılıç, Ö. A. (2011). Halkla Illişkiler 2.0. Ankara: Efil.

Akar, E. (2010). Sanal Toplulukların Bir Türü Olarak Sosyal Ağ Siteleri - Bir Pazarlama Illetişimi Kanalı Olarak İşleyişi. Anadolu Üniversitesi Sosyal Bilimler Dergisi, 10 (1): 107-122.

Altıntaş (2013). Playstation nedir?, https://www.merakname.com/playstation-nedir/ (18 Eylül 2013). 19.02.2017.

Aslan, M. ve Öztürk, S.A. (2015). Marka Topluluğundan Beklenen Faydalar ve Markaya Adanmışıık Illişkisi: Gnctrkcll Marka Topluluğu Üyeleri Üzerine Bir Araştırma. Pazarlama Teorisi ve Uygulamaları Dergisi. 1(2): 61-96.

Bahar, B. (2015). Elektronik Ağızdan Ağıza İletişimin Tüketici Satın Alma Kararlarına Etkisi. Finans Politik \& Ekonomik Yorumlar. 52 (209): 63-72.

BilgiBaba (2016). Playstation Nedir, Tarihi ve Yardımcı Aletleri Nelerdir? (31 Mayıs 2016). http:// www.bilgibaba.org/yazi/playstation-nedir-tarihi-ve-yardimci-aletleri-nelerdir. 19.02.2017.

Blackett, T. (2003). What is a brand?. Brands and Branding. R. Clifton (der.) içinde. London: The Economist. 13-25.

Brymer, C. (2003). What makes brands great. Brands and Branding. R. Clifton (der.) içinde. London: The Economist. 65-76.

Casalo, L.V., Flavian, C. ve Guinaliu, M. (2010). Relationship Quality, Community Promotion and Brand Loyalty in Virtual Communities: Evidence from Free Software Communities. International Journal of Information Management 30, 357-367.

Dedeoğlu, A. O. ve Üstündağlı, E. (2011). Sanal Topluluklar Bağlamında Tüketicilerin Tüketim, Yaşam Tarzı ve Kimlik Yönünden Değerlendirilmesi. Business and Economics Research Journal. 2 (2): 23-40.

Demir, F. O. (2008). "Müşteri Sosyalizasyonunda Marka Toplulukları: Harley Sahipleri Türkiye Grubu Örneği” İstanbul Üniversitesi İletişim Fakültesi Dergisi. 32: 115-128.

Elden, M. (2009). Reklam ve Reklamcılık. İstanbul: Say.

Erdoğan, Z. ve Torun, T. (2009). Bir İlişkisel Pazarlama Aracı Olarak Sanal Topluluklar. Pazarlama 
ve Pazarlama Araştırmaları Dergisi, 4, 45-71.

Gurbetoğlu, A. (2015). Bilimsel Araştırma Yöntemleri (11. 03. 2015). http://agurbetoglu.com/ files/2-\%20ARA\%C5\%9ETIRMA\%20\%20T\%C3\%9CRLER\%C4\%B0.pdf. 18.10.2017.

Gupta, S. ve Kim, H.W. (2004). Virtual Community: Concepts, Implications, and Future Research Directions. Proceedings of the Tenth Americas Conference on Information Systems, New York, August, 2679-2687.

Hazeldine, L. (2015). Brand communities (13 May 2015). https://lewishazeldine.wordpress. com/2015/05/13/brand-communities/. 19.02.2017.

Healy, J.C. ve McDonagh, P. (2013). Consumer Roles in Brand Culture and Value Co-Creation in Virtual Communities . Journal of Business Research 66, 1528-1540.

Hong, P. (2015). 10 Exceptional Examples Of Brand Communities (15 January 2015). https:// www.linkdex.com/en-us/inked/10-exceptional-examples-of-brand-communities/. 19.02.2017.

Islam, J.U. ve Rahman, Z. (2017). The impact of online brand community characteristics on customer engagement: An application of Stimulus- Organism- Response paradigm. Telematics and Informatics. 34 (4): 96-109.

İşlek, M. S. (2012). Sosyal Medyanın Tüketici Davranışlarına Etkileri: Türkiye>deki Sosyal Medya Kullanıcıları Üzerine Bir Araştırma. Yayınlanmamış Yüksek Lisans Tezi. Karaman: KMÜ. SBE.

Jung, N.Y., Kim, S. ve Kim, S. (2014). Influence of consumer attitude toward online brand communitiy on revisit intention and brand trust. Journal of Retailing and Consumer Services 21, 581-589.

Kümbetoğlu, B. (2015). Sosyolojide ve Antropolojide Niteliksel Yöntem ve Araştırma. İstanbul: Bağlam.

Lidstrom, M. (2006). Duyular ve Marka: 5 duyuyla güçlü markalar yaratmak. Çev., Ümit Şensoy. İstanbul: Optimist.

Muniz, A.M. ve O'Guinn, T.C. (2001). "Brand Community”, Journal of Consumer Research. 27 (4): 412-432.

Playstation.com (2017). Oyuna yön verenler, Ev eğlencesi yeniden tanımlanıyor. https://www. playstation.com/tr-tr/footer/about-us/. 26.02.2017.

Popp, B. ve Woratscheck, H. (2016). Introducing branded communities in sport for building strong brand relations in social media. Sport Management Review. 19(2): 183-197.

Rosenthal, B. ve Brito, E.P.Z. (2017). How virtual brand community traces may increase fan engagement in brand pages. Business Horizons, 60(3): 375-384.

Solomon, M.R. (2004). Tüketici Kralığı Fethi. Çev., Selin Çetinkaya. İstanbul: MediaCat.

Tauber, E.M. (1988). Brand Leverage: Strategy for Growth in a Cost-Control World. Journal of Advertising Research, August-September, 26-30.

Tek, Ö. B. ve Özgül, E. (2010). Modern Pazarlama İlkeleri. İzmir: Dokuz Eylül Üniversitesi.

Tosun, N. (2010). İletişim Temelli Marka Yönetimi. İstanbul: Beta.

Tosun, N. (2014). Marka Yönetimi. İstanbul: Beta.

Ural, T. (2009). Markalamada Yol Haritası. Ankara: Nobel.

Uzkurt, C. ve Özmen, M. (2006). Pazarlama Yöneticileri İçin Yeni Bir Fırsat: Sanal Topluluklar. Afyon Kocatepe Üniversitesi Dergisi. VIII (1): 23-40. 
Ventura, K. (2012), "Sanal Marka Topluluklarında Topluluk Üyelerinin Marka ile Özdeşleşme Düzeylerinin Öncülleri ve Sonuçları: Yapısal Bir Model Önerisi” Celal Bayar Üniversitesi i.i..B.F. Yönetim ve Ekonomi Dergisi. 19(2):197-217.

Wang, Y., Ma, S. ve Li, D. (2015). Customer Participation in Virtual Brand Communties: The SelfConsrual Perspective. Information \& Management 52, 577-587.

Wang, Y., Hsiao, S., Yang, Z., ve Hajli, N. (2016). The impact of sellers' social influence on the co-creation of innovation with customers and brand awareness in online communities. Industrial Marketing Management 54, 56-70.

Wu, S., ve Fang, W. (2010). The Effect of Consumer- to- Consumer Interactions on İdea Generation in Virtual Brand Community Relationships. Technovation 30, 570-581.

Wikipedia (2017). "PlayStation”, https://tr.wikipedia.org/wiki/PlayStation. 19.02.2017. 